\title{
A study on Sorghum bicolor (L.) Moench response to split application of herbicides
}

\author{
Sylwia Kaczmarek* \\ Department of Weed Science and Plant Protection Techniques, Institute of Plant Protection - National Research Institute, \\ Władysława Węgorka 20, 60-318 Poznań, Poland
}

Vol. 57, No. 2: 152-157, 2017

DOI: 10.1515/jppr-2017-0021

Received: March 10, 2017

Accepted: May 24, 2017

*Corresponding address:

ior.poznan.sylwia@gmail.com

\begin{abstract}
Field experiments to evaluate the split application of mesotrione $+\mathrm{s}$-metolachlor, mesotrione + terbuthylazine, dicamba + prosulfuron, terbuthylazine + mesotrione + s-metolachlor, and sulcotrione in the cultivation of sorghum var. Rona 1 were carried out in 2012 and 2013. The field tests were conducted at the field experimental station in Winna Góra, Poznan, Poland. Treatments with the herbicides were performed directly after sowing (PE) and at leaf stage 1-2 (AE1) or at leaf stage 3-4 (AE2) of sorghum. The treatments were carried out in a laid randomized block design with 4 replications. The results showed that the tested herbicides applied at split doses were effective in weed control. After the herbicide application weed density and weed biomass were significantly reduced compared to the infested control. The best results were achieved after the application of mesotrione tank mixture with s-metolachlor and terbuthylazine. Application of split doses of herbicides was also correlated with the density, biomass, and height of sorghum.
\end{abstract}

Key words: herbicides, mesotrione, s-metolachlor, sorghum, split doses, terbuthylazine, weed control

\section{Introduction}

Sorghum, the oldest cultivated crop in the world, is classified in Poland as a minor crop due to its small area of cultivation (about 20,000 ha) and lack of labeled herbicides. Interest in sorghum biomass as an important source of renewable energy is continually growing. In central Europe sorghum is cultivated mainly as a bioenergy and forage crop. Environmental and management conditions determine its productivity (Wight et al. 2012). Due to the increasing significance of sorghum in Poland more studies are being carried out in order to gain information about sorghum cultivation, including weed management practices (Kaczmarek et al. 2009; Skrzypczak et al. 2009; Księżak et al. 2012; Kaczmarek et al. 2013).

There are no registered sorghum varieties in Poland, however Polish farmers can successfully cultivate the varieties included in the European Union catalogue. Under European conditions, according to FAO (FAO 2014), grain sorghum is cultivated in 17 countries, on a total area of 390,000 ha. The largest cultivation area is found in Russia (about 150,000 ha) and in Ukraine (about 83,000 ha), with approximate sorghum yields of 15,000 and $26,981 \mathrm{~kg} \cdot \mathrm{ha}^{-1}$ respectively. There is no data for Poland. Sorghum plants can grow under low water conditions and plants are remarkably tolerant of high temperatures (Laidlaw et al. 2009).

Weed control with chemicals is an important factor since sorghum plants grow slowly in early stages, and if weeds are controlled within the first four weeks after crop emergence yield loss will be minimum (Moore et al. 2004). Weeds can compete with sorghum plants and can reduce the sorghum yield (Smith and Scot 2000; Magani 2008). Yield loss due to weeds depends on the duration of weed infestation, the nature and intensity of weeds, the crop cultivars, and environmental conditions (Knezevic et al. 2002; Tamado et al. 2002). Farmers who are interested in sorghum, should have access to scientific information in order to learn how 
to optimize chemical weed control management and improve the efficacy for minimizing the costs.

Sorghum is similar in appearance to corn and is used for many of the same purposes (Getachew et al. 2016). Therefore some of the herbicides registered for corn are also available for weed control in sorghum. But not all herbicides applied in corn are also safe for sorghum plants. In our previous studies (Kaczmarek et al. 2009) a herbicide containing foramsulfuron + iodosulfuron methyl sodium was not safe for sorghum cultivation. In this case, the study results did not verify the hypothesis that herbicide application in corn (Gołębiowska and Rola 2004; Idziak et al. 2006) and in sweet corn (Waligóra and Szpurka 2007) will also be effective for sorghum. Moreover, field tests should also include the sorghum variety factor because of the different responses to weed competition (Wu et al. 2010; Mishra et al. 2015).

The main goal of this study was to evaluate the herbicides applied in low doses for sorghum (var. Rona 1). The main reason for the field studies was the fact that there are still no registered herbicides for weed management for sorghum. It is still an undefined domain in weed management practices for sorghum, including novel methods/applications, environmental concerns and the variety of sorghum.

\section{Materials and Methods}

Fields experiments were carried out in 2012 and 2013 at the field experimental station in Winna Góra located about $60 \mathrm{~km}$ from Poznan, Poland (52 $12^{\prime} \mathrm{N}$; $\left.17^{\circ} 27^{\prime} \mathrm{E}\right)$. The soil of the field in 2012 was sandy loam with pH 5.7 and $1.14 \%$ of organic carbon and in 2013 the soil was loamy sand with $\mathrm{pH} 4.8$ and $0.88 \%$ of organic carbon. Soil size fractions in 2012 and 2013 were as follows: sand $(2-0.05 \mathrm{~mm})-68.99 \%$ and $75.08 \%$; silt $(0.05-0.002 \mathrm{~mm})-27.85 \%$ and $21.03 \%$; loam $(<0.002$ $\mathrm{mm}) 3.16 \%$ and $2.89 \%$.

The following split doses treatments were used in sorghum (pre-emergence and post-emergence): mesotrione + s-metolachlor (Camix $560 \mathrm{SE}, 60 \mathrm{~g} \cdot \mathrm{l}^{-1}+500 \mathrm{~g} \cdot$ $\cdot 1^{-1}$ ), mesotrione + terbuthylazine (Calaris $400 \mathrm{SC}$, $70 \mathrm{~g} \cdot \mathrm{1}^{-1}+330 \mathrm{~g} \cdot \mathrm{1}^{-1}$ ), dicamba + prosulfuron (Casper $\left.55 \mathrm{WG}, 500 \mathrm{~g} \cdot \mathrm{1}^{-1}+50 \mathrm{~g} \cdot \mathrm{1}^{-1}\right)$, terbuthylazine + mesotrione + s-metolachlor (Lumax 537.5 SE, $187.5 \mathrm{~g} \cdot \mathrm{1}^{-1}+$ $+37.5 \mathrm{~g} \cdot \mathrm{l}^{-1}+312.5 \mathrm{~g} \cdot \mathrm{l}^{-1}$ ), sulcotrione (Shado $300 \mathrm{SC}$, $\left.300 \mathrm{~g} \cdot \mathrm{1}^{-1}\right)$. Doses of herbicides per ha are given in Tables 1 and 2. Herbicide application was conducted with a pressure plot sprayer of tank volume 41 , working pressure of 2 bars, nozzle spacing of $50 \mathrm{~cm}$, application rate of $200 \mathrm{l} \cdot \mathrm{ha}^{-1}$, mounting of sprayer beam of $50 \mathrm{~cm}$ and working velocity of $5 \mathrm{~km} \cdot \mathrm{h}^{-1}$. A control object was included, where no chemical weed control was implemented (infested-control). The treatments were carried out in a randomized block design with 4 replications. In both years the plot size was $16.5 \mathrm{~m}^{2}$ (width of $1.5 \mathrm{~m}$, length of $11.5 \mathrm{~m}$ ).

Mineral fertilization was performed before the sowing of sorghum seeds: $\mathrm{N}=16-18 \mathrm{~kg} \cdot \mathrm{ha}^{-1}, \mathrm{P}_{2} \mathrm{O}_{5}=$ $=64-72 \mathrm{~kg} \cdot \mathrm{ha}^{-1}, \mathrm{~K}_{2} \mathrm{O}=72-81 \mathrm{~kg} \cdot \mathrm{ha}^{-1}$. In 2012, the sorghum seeds were sown on May 23 and in 2013 the seeds were sown on the same day, May 23. During both years fertilizer was applied based on the soil test recommendations. The total rainfall received during the growing season (May to October) was $335.5 \mathrm{~mm}$ and $346.3 \mathrm{~mm}$ in 2012 and 2013, respectively. The average temperature was $15.8^{\circ} \mathrm{C}$ and $16.2^{\circ} \mathrm{C}$ respectively. The crop was harvested at the end of October by cutting the plants near ground and then the fresh sorghum biomass (yield) was recorded.

The following data were collected during the vegetating season: the number of weeds, weed biomass, sorghum density, height, and yield (biomass). Weed control efficacy was based on the number and fresh weight of weeds per $1 \mathrm{~m}^{2}$. Weeds were collected from an area of $0.25 \times 0.5 \mathrm{~m}, 3-4$ weeks after the last herbicide treatment. They were then separated according to species, counted, and weighed. Data were calculated per surface area of $1 \mathrm{~m}^{2}$. Sorghum density was measured before harvest by counting sorghum plants in one of the middle rows of each plot. The mean height of sorghum plants was measured before harvest as the average height of 10 plants in the plot. Sorghum yield was determined by calculating the hand-harvested plants of one middle row from each plot. The average data of two years were subjected to one-way ANOVA with post-hoc Tukey HSD and the mean values of treatments were separated using XLSTAT software at $\mathrm{p}<0.05$.

\section{Results}

\section{Effect on weed control}

During the years of research the sorghum cultivation was infested by Echinochloa crus-galli (L.) P. Beauv., Viola arvensis Murray., Geranium pusillum L., Chenopodium album L., Fallopia convolvulus (L.) Á. Löve, Polygonum aviculare (L.), Capsella bursa-pastoris (L.), and Tripleurospermum inodorum (L.) Sch. Bip. Echinochloa crus-galli, the only representative of monocotyledonous weeds, was dominant in the composition of weed infestation. Data analysis showed a significant influence of the herbicide treatments. All the herbicides applied to the plants affected both weed number and weed biomass (Table 1).

After herbicide application the density of dicotyledonous weeds and their biomass were reduced compared 
to the natural infested control. The strongest effect on the dicotyledonous weed number occurred after the split application of mesotrione + terbuthylazine, and terbuthylazine + mesotrione $+s$-metolachlor. Echinochloa crus-galli was also well controlled in most cases. The best option for E. crus-galli control was mesotrione $+s$-metolachlor. Moreover, a positive correlation between application of dicamba + prosulfuron and E. crus-galli density was found.

Weed biomass was also affected by the herbicides (Table 1). Almost all substances, besides dicamba + + prosulfuron, reduced dicotyledonous weeds significantly (herbicide efficacy ranged from $83 \%$ to $97 \%$ ). The highest reduction of weed biomass was recorded on the plots where mesotrione + terbuthylazine, and terbuthylazine + mesotrione $+s$-metolachlor were used. Echinochloa crus-galli biomass was suppressed by other dicotyledonous weeds on the control plots. As a result the monocotyledonous biomass was lower than some plots where herbicides were applied. The highest reduction of E. crus-galli biomass was achieved after the application of terbuthylazine + mesotrione + + s-metolachlor, whereas mesotrione + terbuthylazine and dicamba + prosulfuron were not effective in E. crus-galli control.

\section{Effect on sorghum yield and plants}

Herbicide treatments and their efficacy level influenced the density, height, and biomass of sorghum (Table 2). A positive correlation of the tested herbicides with the density of sorghum was observed for the three split applications: mesotrione $+\mathrm{s}$-metolachlor, terbuthylazine + mesotrione $+s$-metolachlor, and sulcotrione. The same result was found for the sorghum biomass, where crop density recorded with these treatments was significantly higher than the density of crops in the control plots and in the plots where dicamba + prosulfuron were used.

The height of the plants was strongly correlated with the treatment. Plants collected from the control plots were significantly shorter than the plants collected from the herbicide-applied plots. But a negative effect on the height of sorghum also occurred for the dicamba + prosulfuron split application. The highest number of plants was harvested from the plots where terbuthylazine + mesotrione $+s$-metolachlor were tested.

There was a significant, negative correlation on sorghum biomass in two cases: in the infested plots and in the plots where dicamba + prosulfuron were used for weed control. Nevertheless, the biomass harvested from other treatments was significantly higher, and the best results were achieved from the plot where terbuthylazine + mesotrione $+s$-metolachlor were applied.
Correlation coefficients showed that the weed number and biomass significantly affected the sorghum (Table 3). The strongest negative correlation of weed density was found in relation to sorghum height and sorghum biomass. Taking the treatments into account, the application method (herbicides and control plots) was correlated with the height of the sorghum, which was greater than other sorghum traits (sorghum biomass and density).

Generally, it can be concluded that terbuthylazine + mesotrione $+s$-metolachlor were safe for sorghum plants and dicamba + prosulfuron caused sorghum height and biomass reduction. Split application of terbuthylazine + mesotrione $+s$-metolachlor can effectively control dicot- and monocotyledonous weeds.

\section{Discussion}

The results of the field experiments confirmed the usefulness of split application of the tested herbicides. Data from the studies show that the best choice for weed control was achieved after the application of three component herbicides: terbuthylazine + mesotrione $+s$-metolachlor. The tank mixture of mesotrione with s-metolachlor and mesotrione with terbuthylazine were also effective. All of the above mentioned active ingredients are well known in corn weed management, and they are still being tested in field experiments for different application methods (James et al. 2006; Whaley et al. 2009; Skrzypczak et al. 2011; Andr et al. 2014; Radivojevic et al. 2014). For example, mesotrione, chemically derived from a natural phytotoxin obtained from the Callistemon citrinus plant, is effective for preand post-emergence control of weeds in corn. The ED values for mesotrione showed that some species of weeds could be effectively controlled with reduced doses (Pannacci and Covarelli 2009).

Other studies confirmed that mesotrione applied in combination with terbuthylazine and s-metolachlor improved the efficacy for E. crus-galli, Hibiscus trionum, Setaria glauca, and Sorghum halpense (Radivojevic et al. 2014).

Moreover, Mendes et al. (2016) concluded that mesotrione applied alone or in a combination with $s$-metolachlor and terbuthylazine did not influence its sorption or desorption. Mesotrione sorption in this research was primarily affected by the clay mineral content and the soil $\mathrm{pH}$.

Mesotrione, terbuthylazine, and s-metolachlor were also tested in our previous studies on sorghum cultivation as a single application during pre- or post-emergence of weeds (Kaczmarek et al. 2012, 2013). For example, in the field where mesotrione was applied post-emergence, in mixtures, sorghum biomass 

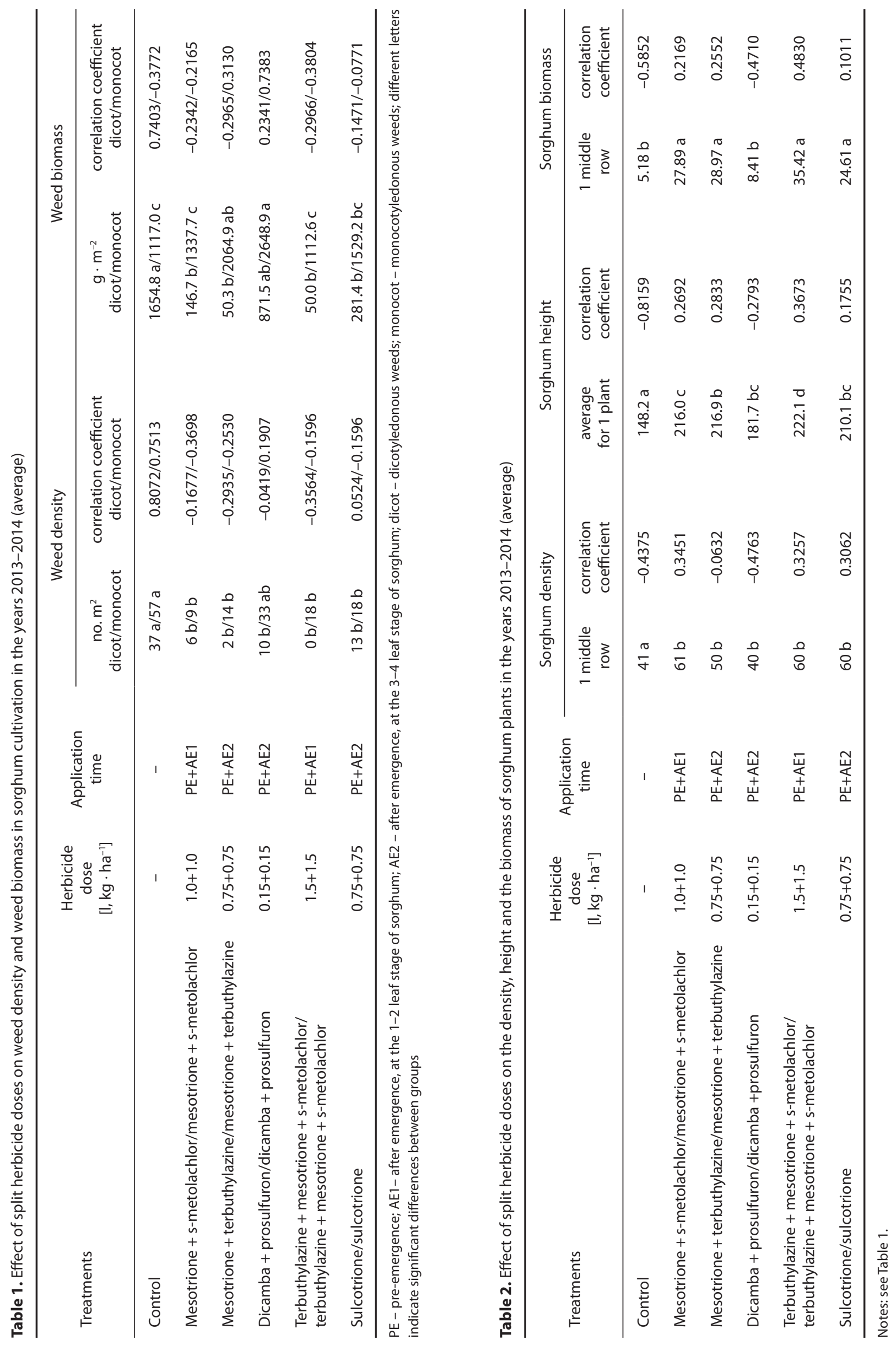
Table 3. Correlation matrix (Pearson) for the height, biomass and density of sorghum and for the number and biomass of weeds (average for years 2013-2014)

\begin{tabular}{|c|c|c|c|c|c|c|c|c|}
\hline Variables & Treatments & $\begin{array}{l}\text { Sorghum } \\
\text { height }\end{array}$ & $\begin{array}{l}\text { Sorghum } \\
\text { biomass }\end{array}$ & $\begin{array}{c}\text { Sorghum } \\
\text { density }\end{array}$ & $\begin{array}{c}\text { Dicot } \\
\text { weeds } \\
\text { number }\end{array}$ & $\begin{array}{l}\text { Monocot } \\
\text { weeds } \\
\text { number }\end{array}$ & $\begin{array}{c}\text { Dicot } \\
\text { weeds } \\
\text { biomass }\end{array}$ & $\begin{array}{c}\text { Monocot } \\
\text { weeds } \\
\text { biomass }\end{array}$ \\
\hline Treatments & 1 & 0.5116 & 0.3822 & 0.3543 & -0.4461 & -0.3797 & -0.4467 & 0.1565 \\
\hline Sorghum height & 0.5116 & 1 & 0.8576 & 0.6499 & -0.7729 & -0.8093 & -0.7927 & -0.0303 \\
\hline Sorghum biomass & 0.3822 & 0.8576 & 1 & 0.8214 & -0.5625 & -0.7029 & -0.6910 & -0.2859 \\
\hline Sorghum density & 0.3543 & 0.6499 & 0.8214 & 1 & -0.3569 & -0.5563 & -0.4497 & -0.3590 \\
\hline $\begin{array}{l}\text { Dicot weeds } \\
\text { number }\end{array}$ & -0.4461 & -0.7729 & -0.5625 & -0.3569 & 1 & 0.6802 & 0.6579 & -0.1698 \\
\hline $\begin{array}{l}\text { Monocot weeds } \\
\text { number }\end{array}$ & -0.3797 & -0.8093 & -0.7029 & -0.5563 & 0.6802 & 1 & 0.7948 & 0.0163 \\
\hline $\begin{array}{l}\text { Dicot weeds } \\
\text { biomass }\end{array}$ & -0.4467 & -0.7927 & -0.6910 & -0.4497 & 0.6579 & 0.7948 & 1 & 0.1015 \\
\hline $\begin{array}{l}\text { Monocot weeds } \\
\text { biomass }\end{array}$ & 0.1565 & -0.0303 & -0.2859 & -0.3590 & -0.1698 & 0.0163 & 0.1015 & 1 \\
\hline
\end{tabular}

Dicot - dicotyledonous; Monocot - monocotyledonous

increased about $57-144 \%$ in comparison to the control plots. Its potential for use in different hybrids of sorghum was also verified by Takano et al. (2016). Experiments conducted in 2012 and 2013 confirmed the usefulness of the split application method in sorghum var. Rona 1 . In most cases the tested herbicides led to the enhancement of sorghum biomass.

The highly efficient new technologies in herbicide production may allow for a reduction of the herbicide doses. Several researchers suggest the possibility of using lower herbicide doses without reducing the yield (Salonen 1992; Zhang et al. 2000; Domaradzki and Rola 2003). Reduced herbicide doses have been successfully used in Europe. Weed composition and their developmental stages are the main factors affecting an herbicide's effectiveness. Therefore species named as sensitive on the label of an herbicide can be successfully controlled with a herbicide dose lower than recommended (Kudsk 1989). Increased herbicide efficacy can be achieved by different strategies, for example by using herbicide mixtures and by repeated reduced amounts of herbicides (Wilson et al. 2005; Deveikyte and Seibutis 2006).

The efficacy of the split applications was tested and confirmed by studies on different crops (Kaps and Ondea 1994; Ferreira et al. 2000; Lockhart and Howatt 2004; Najafi et al. 2013; Idziak and Woźnica 2014). For example, in corn, a reduced dose of tembotrione and its mixture with flufenacet + isoxaflutole and adjuvants applied twice provided corn grain yield similar to the herbicides applied once at the labeled rates (Idziak and Woźnica 2014). In other experiments Idziak et al. (2013) tested split application of mesotrione in sorghum cultivation, with good results. Dose-splitting treatments were also verified by Mathiassen et al. (2007).
Researchers found that the ratio of herbicide doses and the interval between the two applications did not affect the herbicide responses.

\section{References}

Andr J., Hejnak V., Jursik M., Fendrychova V. 2014. Effects of application terms of three soil active herbicides on herbicide efficacy and reproductive ability for weeds in maize. Plant Soil and Environment 60 (10): 452-458.

Deveikyte I., Seibutis V. 2006. Broadleaf weeds and sugar beet response to phenmedipham, desmedipham, ethofumesate and triflusulfuron-methyl. Agronomy Research 4: 159-162.

Domaradzki K., Rola H. 2003. The possibility of weed control in cereals by use low rates of herbicides - review of existing investigations. Journal of Plant Protection Research 43 (2): 163-170.

FAO. 2014. Food and Agricultural Organization of the United Nations. Crops. Available on: http://www.fao.org/faostat/ en/\#data/QC. [Accessed: March 01, 2017]

Ferreira L.R., Durigan J.C., Churata-Masca M.G.C., Ferreira F.A., Silva A.A. 2000. Selectivity and efficacy of the sequential application of oxyflurofen and ioxynyl-octanoate in direct sowing in onion. Planta Daninha 18 (1): 39-50.

Getachew G., Putnam D.H., De Ben C.M., De Peters E.J. 2016. Potential of sorghum as an Alternative to Corn Forage. American Journal Plant Sciences 7: 1106-1121. DOI: http:// dx.doi.org/10.4236/ajps.2016.77106

Gołębiowska H., Rola H. 2004. Efekty niszczenia Elymus repens herbicydami MaisTer 310 WG, Titus 25 WG i Milagro 040 SC w uprawie kukurydzy w warunkach Dolnego Śląska [Evaluation of MaisTer $310 \mathrm{WG}$, Titus $25 \mathrm{WG}$ and Milagro 040 SC efficiency in Elymus repens control in maize crop in the Lower Silesia Region]. Progress in Plant Protection/ Postępy w Ochronie Roślin 44 (2): 695-698. (in Polish, with English abstract)

Idziak R., Woźnica Z., Waniorek W. 2006. Skuteczność chwastobójcza herbicydu MaisTer 310 WG stosowanego $\mathrm{z}$ adiuwantami i nawozem mineralnym. [Evaluation of weed control of herbicide MaisTer 310 WG applied with adjuvants and a mineral fertilizer]. Progress in Plant Protection/Postępy 
w Ochronie Roślin 46: 226-228. (in Polish, with English abstract)

Idziak R., Skrzypczak W., Waligóra H., Woźnica Z. 2013. The effect of mesotrione applied with adjuvants on weed control efficacy and forage sorghum tolerance. Turkish Journal of Agriculture and Forestry 37: 265-270. DOI: 10.3906/tar-1203-29

Idziak R., Woźnica Z. 2014. Impact of tembotrione and flufenacet plus isoxaflutole application, timings, rates, and adjuvant type on weeds and yield of maize. Chilean Journal of Agricultural Research 74 (2): 129-134. DOI: https://doi. org/10.4067/s0718-58392014000200001

James T.K., Rahman A., Hicking J. 2006. Mesotrione - a new herbicide for weed control in maize. New Zealand Plant Protection 59: 242-249.

Kaczmarek S., Matysiak K., Krawczyk R. 2009. Studies of the chemical weed control in Sorghum vulgare PERZ. (Sorghum vulgare PERZ.). Acta Scientiarum Polonorum, Agricultura $8(1): 27-35$

Kaczmarek S., Matysiak K., Kierzek R. 2012. Ocena skuteczności chwastobójczej i selektywności herbicydów stosowanych doglebowo w uprawie Sorghum vulgare Perz. [Weed control efficacy and selectivity of preeemergence herbicides in Sorghm vulgare Perz. Cultivation]. Progress in Plant Protection/Postępy w Ochronie Roślin 52: 47-50. (Polish with English abstract). DOI: http://dx.doi.org/10.14199/ppp-2012-009

Kaczmarek S., Matysiak K., Kierzek R. 2013. Reakcja sorga zwyczajnego (Sorghum biocolor L. Moench) na wybrane herbicydy stosowane nalistnie. [Response of Sorghum bicolor L. Moench to the selected postemergence herbicides]. Fragmenta Agronomica 30 (1): 62-68. (in Polish, with English abstract)

Kaps M.L., Ondea M.B. 1994. Split and tank-mix preemergence application of herbicide for controlling weeds in grapes. HortScience 29: 619-620.

Knezevic S., Evans S., Blankenship E., Van Acker R., Lindquist J. 2002. Critical period for weed control: The concept and data analysis. Weed Science 50 (6): 773-786. DOI: 10.1614/0043-1745(2002)050[0773:CPFWCT]2.0.CO;2

Księżak J., Bojarszczuk J., Staniak M. 2012. The productivity of maize and sorghum yields of according level of nitrogen fertilization. Polish Journal of Agronomy 8: 20-28.

Kudsk P. 1989. Experiences with reduced herbicide doses in Denmark and the development of the concept of factor-adjusted doses. Proceedings, Brighton Crop Protection Conference, Weeds 4: 545-554.

Laidlaw H.K., Godwin I.D. 2009. Sorghum. Compendium of Transgenic Crop Plants 1 (6): 157-176. DOI: 10.1002/ 9781405181099.k0106

Lockahart S.J., Howatt K.A. 2004. Split applications of herbicides at reduced rates can effectively control wild oat (Avena fatua) in wheat. Weed Technology 18 (2): 369-374. DOI: https://doi.org/10.1614/wt-03-100r1

Magani I.E. 2008. Weed control in sorghum - groundnut mixture in the simultaneous farming system of Southern Giunea Savanna zone of Nigeria. The Journal of Animal and Plant Sciences 1 (1): 3-8.

Mathiassen S.K., Ravn H.W., Kudsk P. 2007. Is dose-splitting of graminicides as effective as a single application? Weed Research 47: 252-261. DOI: https://doi.org/10.1111/j.1365$-3180.2007 .00568 . \mathrm{x}$

Mendes K.F., Reis M.R., Inoue M.H., Pimpinato R.F., Tornisielo V.L. 2016. Sorption and desorption of mesotrione alone and mixed with s-metolachlor + terbuthylazine in Brazilian soils. Geoderma 280: 22-28. DOI: https://doi.org/10.1016/ j.geoderma.2016.06.014

Mishra J.S., Rao S.S., Patil J.V. 2015. Response of grain sorghum (Sorghum bicolor) cultivars to weed competition in semi-arid tropical India. The Indian Journal of Agricultural Science 85 (5): 688-694.

Moore J.W., Murray D.S., Westerman R.B. 2004. Palmer amaranth (Amaranthus palmeri) effects on the harvest and yield of grain sorghum (Sorghum bicolor). Weed Technology 18 (1): 2-29. DOI: https://doi.org/10.1614/wt-02-086
Najafi H., Bazoubandi M., Jafarzadech N. 2013. Effectiveness of repeated reduced rates of selective broadleaf herbicides for postemergence weed control in sugar beet (Beta vulgaris). World Journal of Agricultural Research 1 (2): 25-29. DOI: 10.12691/wjar-1-2-1

Pannacci E., Covarelli G. 2009. Efficacy of mesotrione used at reduced doses for pos-emergence weed control in maize (Zea mays L.). Crop Protection 28 (1): 57-61. DOI: https:// doi.org/10.1016/j.cropro.2008.08.011

Radivojević L., Umiljendić J.G., Marisavljević D., Anđelković A., Pavlović D. 2014. The application of mesotrione in combination with terbuthylazine, nicosulfuron and s-metolachlor in maize. Plant Protection 65 (4): 155-162. DOI: https://doi. org/10.5937/zasbilj1404155r

Salonen J. 1992. Yield response of spring cereals to reduced herbicide doses. Weed Research 32 (6): 493-499. DOI: https:// doi.org/10.1111/j.1365-3180.1992.tb01910.x

Skrzypczak W., Waligóra H., Szulc P., Kruczek A. 2009. Ocena skuteczności chwastobójczej i fitotoksyczności herbicydów stosowanych w uprawie sorga. [Assessment of effectiveness and phytotoxicity of herbicides applied in the cultivation of sorghum]. Progress in Plant Protection/Postępy w Ochronie Roślin 49 (2): 832-836. (in Polish, with English abstract)

Skrzypczak G.A., Sobiech Ł., Waniorek W. 2011. Evaluation of the efficacy of mesotriona plus nicosulfuron with additives as tank mixtures used for weed control in maize (Zea mays L.). Journal of Plant Protection Research 51 (3): 300-305. DOI: https://doi.org/10.2478/v10045-011-0049-1

Smith K., Scott B. 2010. Weed control in grain sorghum. p. 4749. In: "Grain Sorghum Production Handbook" (Espinoza L., Kelley J., eds.). Cooperative Extension Service, University of Arkansas, Little Rock, AR, USA, 74 pp.

Takano H.K., Rubin R.S., Marques L.H., Tronquini S.M., Fadin D.A., Kalsing A., Neves R., Júnior O.P. 2016. Potential use of herbicides in different sorghum hybrids. African Journal of Agricultural Research 11 (26): 2277-2285. DOI: https://doi. org/10.5897/ajar2016.11190

Tamado T., Ohlander L., Milberg P. 2002. Interference by the weed Parthenium hysterophorus L. with grain sorghum: influence of weed density and duration of competition. International Journal of Pest Management 48 (3): 183-186. DOI: https://doi.org/10.1080/09670870110101739

Waligóra H., Szpurka W. 2007. Ocena wrazliwosci kilku odmian kukurydzy cukrowej na wybrane herbicydy. [Susceptibility of sugar maize varieties to some herbicides]. Progress in Plant Protection/Postępy w Ochronie Roślin 47 (3): 289291. (in Polish, with English abstract)

Wight J.P., Hons F.M., Storlien J.O, Provin T.L., Shahandeh H., Wiedenfeld R.P. 2012. Management effects on bioenergy sorghum growth, yield and nutrient uptake. Biomass and Bioenergy 46: 593-604. DOI: https://doi.org/10.1016/ j.biombioe.2012.06.036

Whaley C.M., Armel G.R., Wilson H.P., Hines T.E. 2009. Evaluation of s-metolachlor and s-metolachlor plus atrazine mixtures with mesotrione for broadleaf weed control in corn. Weed Technology 23 (2): 193-196. DOI: https://doi.org/ 10.1614/wt-08-123.1

Wilson R.G., Smith J.A., Yonts C.D. 2005. Repeated reduced rates of broadleaf herbicides in combination with methylated seed oil for postemergence weed control in sugarbeet (Beta vulgaris). Weed Technology 19 (4): 855-860. DOI: https://doi.org/10.1614/wt-04-258r1.1

Wu H., Walker S.R., Osten V.A., Robinson G. 2010. Competition of sorghum cultivars and densities with Japanese millet (Echinochloa esculenta). Weed Biology and Management 10 (3): 185-193. DOI: https://doi.org/10.1111/j.1445-6664. 2010.00383.x

Zhang J., Weaver S.E., Hamill A.S. 2000. Risks and reliability of using herbicides at below-labeled rates. Weed Technology 14 (1): 106-115. DOI: https://doi.org/10.1614/0890-037x (2000)014[0106:rarouh]2.0.co;2 